\title{
RELIABILITY AND VALIDITY OF LEARNING STYLE INVENTORY FOR PRIMARY SCHOOL STUDENTS BASED ON THE MYERS-BRIGGS LEARNING STYLE MODEL (ISUMB2-O)
}

ABSTRACT. The goal of this study was to examine reliability and validity of learning styles inventory ISUMB2-O for primary school children. This inventory is based on Myers-Briggs learning style model, and the model itself is based on Jung's personality types. According to this model, the individual's profile is determined based on four pairs of opposite preferences: extraversion/ introversion, sensing/intuition, thinking/feeling, and judgement/perception.

Reliability data (in a sample of 100 students of the $4^{\text {th }}$ grade of primary school in Nis) obtained, both for individual dimensions (expressed by the Cronbach's alpha coefficient) and based on item analysis, indicate that this is a stable instrument. Three out of four dimensions have the reliability over 0.93 expressed by the Cronbach's alpha. Validity was verified in two ways: a) Construct validity was checked by using factor analysis in order to check the factor structure of the instrument, and b) external validity was checked by using the degree of correlation of values obtained based on the dimensions of learning styles with the instrument ISUMB2-O and on the teachers' assessment of individual poles of the examined dimensions of learning styles

dusan.randjelovic@pr.ac.rs

miljana.pavicevic@pr.ac.rs

This paper was submitted on August $24^{\text {th }}, 2020$ and accepted for publication at the meeting of the Editorial Board held on September $25^{\text {th }}, 2020$. 
in their students based on the descriptions they received. The four-factor solution is the optimal and best possible one for the given instrument and it can explain $57 \%$ of the total variance. There is a statistically significant positive correlation between the results for the dimensions of the inventory of learning styles and teachers' assessment of individual poles of the examined dimensions of learning styles in their students based on the descriptions they received. This correlation value is high in the case of dimensions E-I, $\mathrm{S}-\mathrm{N}$ and J-P, and of medium intensity when it comes to the dimension F-T. No differences in learning styles were observed from gender standpoint, while the dimensions sensing-intuition and judgment-perception were found to be related to school achievement.

The conclusion is that the instrument showed good psychometric characteristics, primarily from the aspect of extremely high reliability, high values for item-total correlation, satisfactory validity construct, and also due to adequate external validity, which indicate that the instrument measures the characteristics for which was originally intended. Limitations of the research were also highlighted, especially those related to the sample size.

KEYWORDS: Psychometric characteristic; inventory of learning styles; Myers-Briggs model.

INTRODUCTION

\section{LEARNING STYLES}

For many years, experts in the field of educational psychology have focused their research primarily on learning objectives, while the learning process itself has been neglected. The emphasis was on what students learn and what results they achieve; primarily expressed by the grades they receive. Recent research trends, especially in the field of learning psychology, are focused on the learning process itself, i.e. the focus has changed from the question "what" and "how much" to the question "how" (Ranđelović, 2016, p. 56).

The importance of cognitive styles, learning styles, specific procedures and learning strategies in regard to individual's learning have been recognized, while regarding the organization of teaching (at all levels: primary, secondary, and even universities), research attention is focused on the need for a more efficient individualization of teaching (Ranđelović, 2013).

As for the learning styles, multiple models and classifications of different learning styles have been postulated in the last thirty 
years. Speaking about the need to respect individual differences among students, Stojaković (Stojaković, 2000) explains the different divisions of cognitive styles and learning styles depending on the researcher's approach.

Learning styles can be most broadly defined as the individuals' preferred way of learning (Pritchard, 2009). However, there are many more complex definitions found in literature, depending on the theoretical basis to which the authors refer. For example, Kolb (Kolb, 1984) defines learning style as a way of grasping and transforming experience. When trying to emphasize the need for a comprehensive approach to learning styles, the author Stojaković (Stojaković, 2000), and later in a slightly modified form the author Randjelović (Randjelović, 2012) claim that learning styles should be seen as characteristic ways of receiving, processing and using information during the process of learning (Randjelović, 2012). Witkin and Goodenough (1981) talk about field independent and field dependent cognitive styles, taking as a criterion the characteristics of processes of perception, which each individual possesses. Gardner's theory of multiple intelligences (1983) states that each of these (logical-mathematical, verbal-linguistic, visual-spatial, bodily-kinesthetic, musical-rhythmic, interpersonal and intrapersonal) has a corresponding and appropriate learning style. Hetfield (Hatfield, 1968, according to Kvaščev, 1978) examined the links between creativity, cognitive style and student achievement in school, and Harrison (Harrison, 1970, according to Kvaščev, 1978) examined the links between cognitive personality type and selective attention, and stated that "subjects with a developed analytical style have a more developed selective attention compared to individuals who have a developed non-analytical style".

Renner (Renner, 1970, according to Kvaščev, 1980) concludes that "cognitive personality type is learned and that it is largely acquired through learning and the organization of experience". Bjekić speaks of learning styles as an established and dominant way of receiving, processing and using stimuli or information in the learning process, and is most recognizable during organized learning in the classroom; it is the predominant way of mentally presenting and processing learning content (Bjekić \& Dunjić Mandić 2007).

Learning styles most frequently mentioned within education are: Myers-Briggs learning style model; Dunn and Dunn Learning Style Model; Felder-Silverman - Learning Style Model; Kolb's learning 
styles model. All of the above learning style model have in common the effort to improve the teaching process and improve student achievement. Based on a large number of studies, Curry (1983) classified learning styles into three layers: personality, information processing, and preferred teaching style. Each of these three categories include three instruments that measure the same construct, using the onion analogy, which is why this classification is called Curry's Onion Model. Personality traits are the inner layer which includes the personality assessment instruments: Witkin's Embedded Figures Test, Myers-Briggs Type Indicator and Kagan's Matching Familiar Figures Test. The middle layer is the layer of information processing that is described as the intellectual approach of an individual to information processing. This layer includes Kolb's Learning Style Inventory, Tamir and Cohen's Cognitive Preferences Inventory, and the Inventory of Learning Processes by Schmeck, Ribich, and Ramaniah. The third layer refers to instructional preferences in the learning process. This category includes Friedman's and Stritter's Instructional Preference Questionnaire, Rezler's and Rezimovich's Learning Preferences Inventory, and The Grasha-Riechmann Student Learning Styles Scale. Curry (1983) defined the fourth layer, which refers to social interaction, i.e. the interaction of an individual with peers during learning. The instruments that measure the social interaction of students are the same instruments that are used for teaching method preferences. According to The Dunn and Dunn Learning Style Model, the learning style implies the way in which each learner begins to concentrate on, process, and retain new information (Dunn \& Dunn, 1993, according to Dunn \& al., 2009). According to this learning style model, there are 21 elements that affect the effectiveness of learning. These elements are classified into five categories: learning environment; emotional preferences; social preferences; physiological preferences and cognitive preferences.

Felder and Silverman (1988) developed The Felder-Silverman learning style model (FSLSM), according to which individuals differ in their preferred way of perceiving, processing, organizing, and understanding information. Each student's profile is characterized by four pairs of opposite preferences: sensing/intuition, visual/ verbal, active/reflective and sequential/global. According to the way of perceiving information - sensory and intuitive, according to the preferred type of information - visual and verbal, according to the way students process perceived information - active and reflec- 
tive, and according to the way of understanding information sequential and global. Felder-Silverman's learning style model is accompanied by the questionnaire The Index of Learning styles questionnaire (ILS).

Kolb's learning style model relies on the work of prominent scientists, especially John Dewey, Kurt Lewin, Jean Piaget, William James, Carl Jung and others whose theories view experience as the central concept. The model is based on six fundamental assumptions (Kolb \& Kolb, 2005). The first assumption is that Kolb believed that learning is not the end result, but a process. According to the second assumption, every learning process is a reconstruction of knowledge and includes a re-examination of what has already been learned. The third assumption stipulates that learning requires the resolution of conflicts between dialectically opposed modes of adaptation to the world. During the process of learning, a person relies on observation and action, feeling and thinking. According to the fourth assumption, learning is a holistic process of adaptation to the world. Learning involves the integrated functioning of the total person. According to the fifth assumption, the knowledge acquired during learning is the result of the interaction between a person and the environment. The sixth assumption presumes that experiential learning theory advocates the constructivist learning theory which sees knowledge as a product of individual's own constructions. In other words, the outcome of learning is the construct of one's own knowledge of the world. This assumption stands in contradiction to the model that implies the transfer of knowledge to students, which education practice is mainly based on.

One of the modern learning style models that has been vastly used in practice (both in education and in the field of marketing as well as in industry) is the Myers-Briggs learning style model based on Jung's personality typology. The MBTI (The Myers-Briggs Type Indicator) instrument was designed in 1943 to assess student-learning styles (Zhang \& Stenberg, 2011). With MBTI, it is possible to assess learning styles presented as four personality type polarities: extraversion/introversion, sensing/intuition, thinking/feeling, and judgement/perception (Coffield \& al., 2004; Li, Chen, \& Tsai, 2008; Pušina, 2014; Stojaković, 2000). According to this concept, there are two ways of interacting with the outside world: extraversion (E) and introversion (I). Extroverts are characterized by social interaction, they make new friends easily, they are action-oriented, relaxed, and optimistic, and collaborative learning suits them. 
Introverts, on the other hand, are focused on their own inner world, love privacy and silence, are focused on a smaller number of people, they are withdrawn and pessimistic (Li, Chen, \& Tsai, 2008; Stojaković, 2000) and prefer to study alone. From the aspect of the way of perceiving information, a person can be a sensing (S) or intuitive type $(\mathrm{N})$. Sensing type personalities predominantly rely on facts gathered through the senses, are focused on the present and specific details, and therefore prefer to solve practical and realistic tasks. Intuitive types have a wide range of different interests, are able to utilize ideas, are focused on solving tasks that require novelty because they do not like routine and repetition, are focused on intuition and finding new solutions to problems (Stojaković, 2000), they like dealing with fundamental science content. Depending on the way the perceived information is processed, people can be thinking $(\mathrm{T}$, ) or feeling type $(\mathrm{F})$. Thinking type is characterized by analytical thinking and decision-making based on logical and objective analysis of causes and consequences, while the feeling type base their actions and decisions on subjective assessment (Stojaković, 2000). The last dichotomy reflects a person's preference toward judgment $(\mathrm{J}$ ) or perception $(\mathrm{P})$. The processes of perception and judgment indicate how the individual perceives the world and how he or she makes connections between things and events. People with more pronounced judgment trait have the ability to organize, plan, and work in accordance with a pre-arranged program and deadlines. Unlike the judgment type, the perceptive type of personality is characterized by flexibility, spontaneity, curiosity, orientation to the process itself, and not to the outcome (Stojaković, 2000); research work and creative problem solving suit them. Most people's characteristics are in-between these extremes or to some extent lean towards one of the four bi-polar dimensions (Stojaković, 2000). In accordance with this point of view, and by using the MBTI instrument, there are 16 personality types derived from all possible combinations of the four bi-polar dimensions. For example, the ISTJ personality type is a sensitive type who is introverted and prefers meaningful judgment. These people are characterized by composure, orderliness, practicality, logic, dedication, etc. (Pušina, 2014). Despite the disputed validity of this instrument, the MBTI is one of the widely used instruments (Salter, Evans, \& Forney, 2006; Zhang \& Sternberg, 2011).

As a shorter version of the MBTI personality inventory, the Paragon Learning Style Inventory PLSI was created, which is used for 
individuals above 8 years of age (Shindler, 2003). This questionnaire consists of 52 items. Within each item, there are two sub-items and the respondent is supposed to choose one of these. Assessment is quantitative. Based on the answers, it can be determined which learning style a person uses: Extraversion (E) - Introversion (I), Sensing (S) - Intuition (N), Thinking $(\mathrm{T})$ - Feeling $(\mathrm{F})$, Judgment $(\mathrm{J})$ - Perception (P). The first dimension (Extraversion/ Introversion) implies the relationship of an individual to others, the second dimension (Sensing-Intuition) represents the time it takes an individual to receive information, the third (Thinking-Feeling) shows how long it takes for a person to make a decision, and the fourth (Judgment-Perception) shows the relative importance of the second and third dimension. The combination of the four preferences determines the learning style which is represented by four letters, one letter from each pair (e.g. ESTP, ENFP). The author states that there are two versions of the instrument: a) for pupils and b) for students (Shindler, 2004). Some initial studies, according to Shindler (2003), speak in favor of the instrument's solid psychometric characteristics, noting that the test-retest method that checked the reliability of the instrument, PLSI inventory showed stability of $60-70 \%$, and in regard to reliability expressed by the model of internal consistency, the Cronbach's alpha is almost always above 0.90 (Shindler, 2004). Other studies too, (for example: Garner-O'Neale \& Harrison, 2013; Aliakbari \& Abol-Nejadian, 2015; Khaki, Ganjabi \& Khodamoradi, 2015) in which the PLSI instrument was used, confirmed high reliability of the instrument as well as other metric characteristics.

In addition to conceptual problems and the discussion of learning styles from different perspectives, the specific problem in research practice is measuring learning styles. After analyzing a large number of learning style models and theories, Cassidy (2004) tried to systematize as many as 23 different models and in his study presents various instruments for measuring these constructs.

In his doctoral dissertation, the author Randjelović (2012), adapted the PLSI instrument and after translation and modified, constructed an instrument that was adapted to the population in Serbia. The author applied the instrument to students in the younger grades of primary school and the instrument showed solid psychometric characteristics, especially the reliability that ranged for all dimensions between 0.767 and 0.953 . The instrument is called the Inventory of Learning Styles according to the Myers 
Briggs model (ISUMB2-O). The application of this instrument proved to be very suitable for identifying student learning styles and later for the construction and implementation of individualized learning programs for students based on student learning styles. In his research, Randjelovic proved that individualized learning based on student learning styles (identified with the help of the ISUMB2-O instrument) provides significantly better results in learning outcomes (seen through the parameters of knowledge, motivation and emotional experience of the lesson) compared to traditional teaching style which does not take into consideration student learning styles. Bearing all the above in mind, the aim of this paper is to check some psychometric characteristics of the ISUMB2-O instrument in a sample of $4^{\text {th }}$ grade primary school students.

\section{METHOD}

\section{SAMPLE}

Non-random and convenience sampling was used. It included $4^{\text {th }}$ grade students from 3 primary schools in Niš ("Njegos" Primary School, "Sveti Sava" Primary School and "Car Konstantin" Primary School). The initial sample consisted of 120 students, but subsequent reduction eliminated from the sample data from all those questionnaires that were incomplete, and data related to respondents that proved to be unreliable, so that the final sample included 100 respondents. The sample is almost equal concerning gender: 48 male students and 52 female students. The students were 10 and 11 years old (average age was 10.23). The average grade of the examined students was 4.42 (on a scale from 1 to 5). The sample also included six teachers (class teachers) whose students filled out the given inventory of learning styles. Teachers were involved for the purpose of external assessment of the presence of certain dimensions of students' learning styles (external validity of instrument).

\section{PROCEDURE}

The survey was conducted in April of the 2017/18 school year. With the consent of teachers and parents of the children who participat- 
ed in the research, students filled out questionnaires during one school lesson (45 min). Concerning teachers, they first received a detailed description of the dimensions of student learning styles with characteristics and preferences for each of the poles of the MB learning style models dimensions. Furthermore, on a separate form they assessed each student on which pole of each learning style dimension he/she preferred (E or I, S or I, F or T, J or P).

\section{INSTRUMENT DESCRIPTION}

ISUMB2-O. The inventory of learning styles for primary school children is based on the Myers-Briggs learning style model. The instrument relies on The Paragon Learning Style Inventory (Shindler, 2004) and was first used for the Serbian population in the paper written by Randjelović (Randjelović, 2012). Randjelovic states (Randjelovic, 2012, p. 128) that the initial version of the instrument contained 52 items and fully corresponded to The Paragon Learning Style Inventory (Student learning style inventory version 52b, Shindler, 2004). The inventory was translated into Serbian and adapted for the population of fourth grade primary school students. After several pilot studies $(\mathrm{N}>850)$ in samples of $4^{\text {th }}, 5^{\text {th }}, 6^{\text {th }}$ and $7^{\text {th }}$ grade students attending primary schools in Nis and Kosovska Mitrovica, the final form of the instrument with 64 items (16 items for each dimension) was created. The final version differs significantly from The Paragon inventory (only $25 \%$ of original items overlap). After the final form of the instrument was used in a sample of fourth grade primary school students in Nis, stable metric characteristics of the instrument were obtained. The instrument proved to be highly reliable, and Cronbach's alpha coefficient ranged from 0.767 for the feeling-thinking dimension, to 0.9536 for the sensing-intuition dimension (Randjelovic, 2012). All items contain statements to which respondents respond by choosing one between the two answer choices (dichotomous type question). The total scores (total number of $a$ or $b$ choices) are calculated for each of the poles of the MB model dimensions, and the respondent is assigned a letter representing the dominant pole of a specific dimension depending on whether he or she had more $a$ or $b$ answer choices. The instrument is a shorter form of Myers Briggs inventory for measuring learning styles and includes four dimensions based on Jung's personality typology (extraversion-introversion, sensing-intuition, thinking-feeling, relying on judgment-relying on 
perception). As a result of the combination between dominant poles of all four dimensions, each student will be classified into one of 16 possible types of learning styles (ISTJ, ISFJ, INFJ, INTJ, ISTP, ISFP, INFP, INTP, ESTP, ESFP, ENFP, ENTP, ESTJ, ESFJ, ENFJ, ENTJ). All of these 16 types can be grouped into four categories (Shindler, 2004) based on the combination of extraversion-introversion and sensing-intuition dimensions: ES - extravert, sensing, EN - extravert, intuitive, IS - introvert, sensing, IN - introvert, intuitive. Randjelovic (2012) states that this instrument is intended for $4^{\text {th }}$ to $8^{\text {th }}$ grade students.

\section{RESULTS}

The overview of results will first present the main descriptive indicators and information related to the reliability of the instrument, followed by the analysis of the instrument validity and lastly the relationship between the values of certain dimensions of MB learning style models and certain sociodemographic variables will be mentioned.

\section{DESCRIPTIVE PARAMETERS AND INSTRUMENT RELIABILITY}

Firstly, descriptive parameters will be presented as well as the reliability of all dimensions of the measured learning styles according to the MB model.

Table 1 shows the reliability of the Learning Style Inventory scales.

\begin{tabular}{||l|l|r|r|r|r|r|}
\hline DIMENSION & \multicolumn{1}{|c|}{ CONTENTS } & N & $\begin{array}{r}\text { NO. OF } \\
\text { ITEMS }\end{array}$ & AS & SD & $\begin{array}{c}\text { CRONBACH'S } \\
\text { ALPHA }\end{array}$ \\
\hline E-I & Extraversion - Introversion & 100 & 16 & 5.84 & 4.82 & 0.931 \\
\hline S-iN & Sensing - Intuition & 100 & 16 & 6.71 & 6.00 & 0.955 \\
\hline F-T & Feeling - Thinking & 100 & 16 & 6.91 & 3.66 & 0.783 \\
\hline J-P & Judgment - Perception & 100 & 16 & 7.44 & 5.857 & 0.947 \\
\hline
\end{tabular}

TABLE 1. RELIABILITY OF THE LEARNing STYLE InVENTORY SCALES [TABELA 1. POUZDANOST SKALA INVENTARA STILOVA UČENJA] 
Based on the data from Table 1, we see that all examined dimensions of learning styles have reliability expressed by the Cronbach's alpha coefficient over 0.78 , and this value is over 0.93 in as many as three of the four dimensions.

Reliability at the level of individual items (item analysis) is shown in Tables 2.1 to 2.4 .

\begin{tabular}{|c|c|c|c|c|}
\hline ITEM & $\begin{array}{c}\text { SCALE MEAN IF ITEM } \\
\text { DELETED }\end{array}$ & $\begin{array}{l}\text { SCALE VARIANCE IF } \\
\text { ITEM DELETED }\end{array}$ & $\begin{array}{l}\text { CORRECTED ITEM-TO- } \\
\text { TAL CORRELATION }\end{array}$ & $\begin{array}{l}\text { CRONBACH'S ALPHA IF } \\
\text { ITEM DELETED }\end{array}$ \\
\hline 01 & 5.50 & 20.475 & .610 & .919 \\
\hline 05 & 5.69 & 20.923 & .693 & .917 \\
\hline 08 & 5.65 & 20.735 & .679 & .917 \\
\hline 10 & 5.35 & 20.028 & .678 & .917 \\
\hline 11 & 5.67 & 20.789 & .696 & .917 \\
\hline 15 & 5.66 & 20.833 & .666 & .917 \\
\hline 18 & 5.32 & 19.735 & .749 & .914 \\
\hline 21 & 5.36 & 20.415 & .586 & .920 \\
\hline 23 & 5.06 & 22.380 & .197 & .929 \\
\hline 26 & 5.68 & 20.806 & .710 & .917 \\
\hline 29 & 5.42 & 19.983 & .699 & .916 \\
\hline 36 & 5.63 & 20.700 & .660 & .917 \\
\hline 39 & 5.70 & 20.899 & .724 & .916 \\
\hline 42 & 5.21 & 21.097 & .448 & .924 \\
\hline 50 & 5.35 & 19.846 & .721 & .915 \\
\hline 51 & 5.35 & 20.088 & .663 & .917 \\
\hline
\end{tabular}

TABLE 2.1. ITEM ANALYSIS OF ITEMS ON THE EXTRAVERSION-INTROVERSION DIMENSION (E-I) [TABELA 2.1. AJTEM ANALIZA STAVKI NA DIMENZIJI EKTRAVERZIJA-INTROVERZIJA (E-I)]

\begin{tabular}{|c|c|c|c|c|}
\hline ITEM & $\begin{array}{l}\text { SCALE MEAN IF } \\
\text { ITEM DELETED }\end{array}$ & $\begin{array}{l}\text { SCALE VARIANCE IF ITEM DE- } \\
\text { LETED }\end{array}$ & $\begin{array}{c}\text { CORRECTED } \\
\text { ITEM-TOTAL COR- } \\
\text { RELATION }\end{array}$ & $\begin{array}{l}\text { CRONBACH'S ALPHA IF } \\
\text { ITEM DELETED }\end{array}$ \\
\hline 04 & 6.37 & 33.306 & .465 & .955 \\
\hline
\end{tabular}

TABLE 2.2. ITEM ANALYSIS OF ITEMS ON THE SENSING-INTUITION DiMENSION (S-IN) [TABELA 2.2. AJTEM ANALIZA STAVKI NA DIMENZIJI SENZACIJA - INTUICIJA (S-IN)] 
Collection of Papers of the Faculty of Philosophy L(3)/2020

\begin{tabular}{|c|c|c|c|c|}
\hline 07 & 6.19 & 31.630 & .744 & .949 \\
\hline 12 & 6.22 & 31.850 & .703 & .950 \\
\hline 14 & 6.33 & 31.637 & .767 & .949 \\
\hline 17 & 6.40 & 32.283 & .679 & .951 \\
\hline 20 & 6.23 & 30.886 & .887 & .947 \\
\hline 25 & 6.27 & 31.290 & .815 & .948 \\
\hline 28 & 6.31 & 31.327 & .820 & .948 \\
\hline 32 & 6.29 & 31.602 & .760 & .949 \\
\hline 35 & 6.43 & 32.995 & .557 & .953 \\
\hline 45 & 6.33 & 32.324 & .635 & .952 \\
\hline 48 & 6.32 & 31.291 & .831 & .948 \\
\hline 58 & 6.23 & 31.755 & .721 & .950 \\
\hline 62 & 6.28 & 31.173 & .840 & .948 \\
\hline 63 & 6.16 & 32.095 & .660 & .951 \\
\hline 64 & 6.29 & 31.622 & .756 & .949 \\
\hline \hline
\end{tabular}

TABLE 2.2. ITEM ANALYSIS OF ITEMS ON THE SENSING-INTUITION DIMENSION (S-IN) [TABELA 2.2. AJTEM ANALIZA STAVKI NA DIMENZIJI SENZACIJA - INTUICIJA (S-IN)]

\begin{tabular}{|c|c|c|c|c|}
\hline ITEM & $\begin{array}{l}\text { SCALE MEAN IF } \\
\text { ITEM DELETED }\end{array}$ & $\begin{array}{l}\text { SCALE VARIANCE IF ITEM DE- } \\
\text { LETED }\end{array}$ & $\begin{array}{c}\text { CORRECTED } \\
\text { ITEM-TOTAL COR- } \\
\text { RELATION }\end{array}$ & $\begin{array}{l}\text { CRONBACH'S ALPHA IF } \\
\text { ITEM DELETED }\end{array}$ \\
\hline 02 & 6.73 & 10.765 & .335 & .748 \\
\hline 09 & 6.59 & 10.628 & .342 & .748 \\
\hline 12 & 6.54 & 12.372 & -.180 & .794 \\
\hline 16 & 6.80 & 11.192 & .218 & .757 \\
\hline 19 & 6.65 & 9.664 & .688 & .714 \\
\hline 22 & 6.84 & 10.600 & .480 & .738 \\
\hline 24 & 6.49 & 11.283 & .135 & .767 \\
\hline 30 & 6.47 & 9.989 & .555 & .727 \\
\hline 33 & 6.73 & 11.775 & .001 & .776 \\
\hline
\end{tabular}

TABLE 2.3. ITEM ANALYSIS OF ITEMS ON THE FEELING-THINKING DIMENSION (F-T) [TABELA 2.3. AJTEM ANALIZA STAVKI NA DIMENZIJI OSEĆANJE-MIŠLJENJE (F-T)] 
ReLIABILITY AND VALIDITY OF LEARNING STYLE INVENTORY FOR PRIMARY SCHOOL STUDENTS

\begin{tabular}{|r|r|r|r|r|}
\hline 37 & 6.33 & 10.587 & .397 & .743 \\
\hline 40 & 6.25 & 10.795 & .373 & .745 \\
\hline 43 & 6.31 & 10.923 & .289 & .752 \\
\hline 46 & 6.55 & 9.684 & .657 & .717 \\
\hline 52 & 6.61 & 9.513 & .729 & .710 \\
\hline 53 & 6.73 & 11.068 & .231 & .757 \\
\hline 54 & 6.83 & 10.466 & .523 & .734 \\
\hline \hline
\end{tabular}

TABLE 2.3. ITEM ANALYSIS OF ITEMS ON THE FEELING-THINKING DIMENSION (F-T) [TABELA 2.3. AJTEM ANALIZA STAVKI NA DIMENZIJI OSEĆANJE-MIŠLJENJE (F-T)]

\begin{tabular}{|c|r|r|r|r|}
\hline & $\begin{array}{l}\text { SCALE MEAN IF } \\
\text { ITEM DELETED }\end{array}$ & $\begin{array}{c}\text { SCALE VARIANCE IF ITEM DE- } \\
\text { LETED }\end{array}$ & $\begin{array}{c}\text { CORRECTED } \\
\text { ITEM-TOTAL COR- } \\
\text { RELATION }\end{array}$ & $\begin{array}{c}\text { CRONBACH'S ALPHA IF } \\
\text { ITEM DeLETED }\end{array}$ \\
\hline 03 & 7.05 & 30.917 & .670 & .945 \\
\hline 06 & 7.12 & 30.713 & .726 & .944 \\
\hline 27 & 7.07 & 30.591 & .736 & .944 \\
\hline 31 & 7.11 & 30.564 & .752 & .943 \\
\hline 34 & 7.02 & 29.838 & .876 & .941 \\
\hline 38 & 7.00 & 30.040 & .836 & .941 \\
\hline 41 & 7.03 & 30.272 & .792 & .942 \\
\hline 44 & 7.28 & 32.264 & .511 & .948 \\
\hline 47 & 7.03 & 30.878 & .675 & .945 \\
\hline 49 & 6.96 & 30.423 & .766 & .943 \\
\hline 55 & 7.04 & 29.675 & .910 & .940 \\
\hline 56 & 6.90 & 32.657 & .357 & .951 \\
\hline 57 & 7.02 & 29.737 & .896 & .940 \\
\hline 59 & 7.00 & 30.040 & .836 & .941 \\
\hline 60 & 7.12 & 32.066 & .467 & .949 \\
\hline 61 & 6.90 & 31.808 & .516 & .948 \\
\hline \hline
\end{tabular}

TABLE 2.4. ITEM ANALYSIS OF ITEMS ON THE JUDGMENT-PERCEPTION DIMENSION (J-P) [TABELA 2.4. AJTEM ANALIZA STAVKI NA DIMENZIJI RASUĐIVANJE-PERCEPCIJA (J-P)] 
INSTRUMENT Validity was verified in two ways: a) Construct validity was checked VALIDITY by using factor analysis in order to check the factor structure of the instrument, and b) external validity was checked by using the degree of correlation of values obtained based on the dimensions of learning styles with the instrument ISUMB2-O and on the teachers' assessment of individual poles of the examined dimensions of learning styles in their students based on the descriptions they received.

CONSTRUCT Factor analysis - the principal component method was used to verVALIDITY ify construct validity. Firstly, the number of selected factors was checked by using Scree Plot and Kaiser Criterion. Varimax rotation was used for factor rotation. The four-factor structure of the instrument was checked. The results of the factor analysis are given in Graph 1 and Tables 3, 4 and 5. It should be noted that the sample size $(\mathrm{N}=100)$ was such that the results of the factor analysis should be considered carefully, since some authors (Tabachnick \& Fidell, 2007) insist that the number of respondents should be at least 5 times larger than the number of items.

\begin{tabular}{|c|c|c|c|c|c|c|c|c|c|}
\hline \multirow[b]{2}{*}{$\begin{array}{l}\text { 䇋 } \\
\text { o } \\
\text { o } \\
0\end{array}$} & \multicolumn{3}{|c|}{ INITIAL EIGENVALUES } & \multicolumn{3}{|c|}{$\begin{array}{l}\text { EXTRACTION SUMS OF } \\
\text { SQUARED LOADINGS }\end{array}$} & \multicolumn{3}{|c|}{$\begin{array}{c}\text { ROTATION SUMS OF SQUARED } \\
\text { LOADINGS }\end{array}$} \\
\hline & $\underset{\leftarrow}{\overrightarrow{5}}$ & 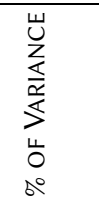 & 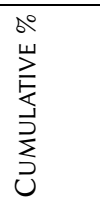 & 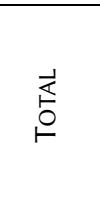 & 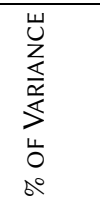 & 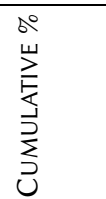 & 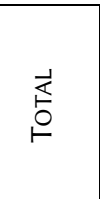 & 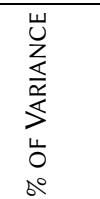 & 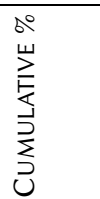 \\
\hline 1 & 19.714 & 30.803 & 30.803 & 19.714 & 30.803 & 30.803 & 19.018 & 29.715 & 29.715 \\
\hline 2 & 8.799 & 13.749 & 44.552 & 8.799 & 13.749 & 44.552 & 7.884 & 12.319 & 42.034 \\
\hline 3 & 4.988 & 7.794 & 52.346 & 4.988 & 7.794 & 52.346 & 4.987 & 7.792 & 49.826 \\
\hline 4 & 3.211 & 5.017 & 57.363 & 3.211 & 5.017 & 57.363 & 4.824 & 7.537 & 57.363 \\
\hline \multicolumn{10}{|c|}{ EXtRaction Method: Principal Component Analysis. } \\
\hline
\end{tabular}

TABLE 3. CHARACTERISTIC ROOTS AND PROPORTION OF EXPLAINED VARIANCE FOR EXTRACTED FACTORS BASED ON THE PRINCIPAL COMPONENT METHOD [TABELA 3. KARAKTERISTIČNE VREDNOSTI I PROCENTI OBJAŠNJENIH VARIJANSI ZA FAKTORE EKSTRAHOVANE NA OSNOVU METODE GLAVNIH KOMPONENTI]

The solution of four separate factors explains around $57 \%$ of the total variance. 


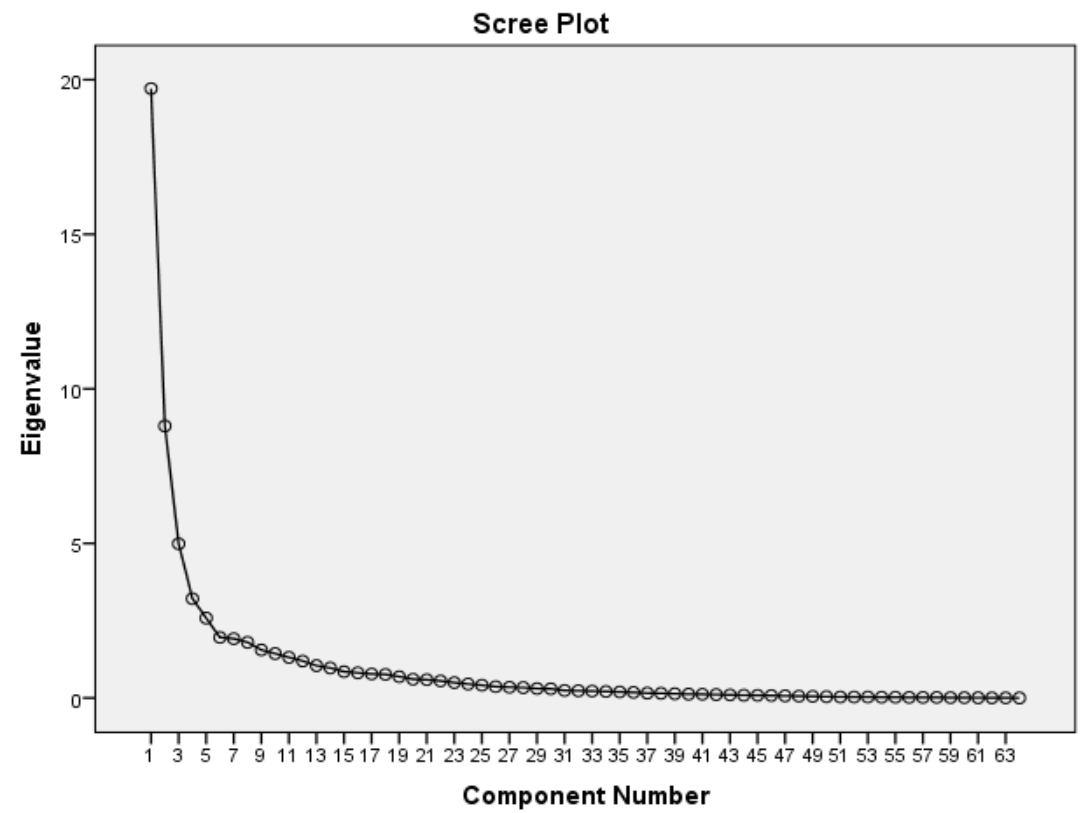

GRAPH 1. SCREE PLOT FOR EXTRACTED FACTORS

Due to the inconsistency of the criteria used to select the extracted factors (The Guttman-Kaiser Criterion and Cattell's scree test), Horn's Parallel Analysis was performed in order to verify the justification of retaining the four-factor solution, and the results are shown in Table 4.

\begin{tabular}{|c|r|r|c|}
\hline $\begin{array}{c}\text { COMPONENT NUM- } \\
\text { BER }\end{array}$ & $\begin{array}{c}\text { ACtUAL CHARACTERISTIC ROOT } \\
\text { FROM PCA }\end{array}$ & $\begin{array}{c}\text { VAlUE OBTAINED BY THE PARALLEL } \\
\text { ANALYSIS }\end{array}$ & DeCISION \\
\hline 1 & 19.714 & 3.0392 & accept \\
\hline 2 & 8.799 & 2.8269 & accept \\
\hline 3 & 4.988 & 2.6750 & accept \\
\hline 4 & 3.211 & 2.5536 & accept \\
\hline 5 & 2.352 & 2.4320 & reject \\
\hline 6 & 1.957 & 2.3370 & reject \\
\hline \hline
\end{tabular}

TABLE 4. COMPARISON OF CHARACTERISTIC ROOTS OBTAINED IN PCA AAND THRESHOLD VALUES OBTAINED BY THE PARAllel ANALYsis [TABELA 4. PoREĐENJE KARAKTERISTIČNIH VREDNOSTI DOBIJENIH U PCA I VREDNOSTI PRAGA DOBIJENIH PARALELNOM ANALIZOM]

a PCA-Principal Component analysis 
The results in Table 4 indicate that the four-factor solution is acceptable.

\begin{tabular}{|c|c|c|c|c|c|}
\hline \multirow{2}{*}{ \#ITEM } & \multirow[b]{2}{*}{ CONTENT } & \multicolumn{4}{|c|}{ COMPONENT } \\
\hline & & 1 & 2 & 3 & 4 \\
\hline 55 & When I study something, I usually do it... & .943 & & & \\
\hline 57 & I like to do things... & .923 & & & \\
\hline 34 & I prefer... & .903 & & & \\
\hline 62 & When I need to do something very important, I do it... & .885 & & & \\
\hline 20 & I like work that requires... & .883 & & & \\
\hline 38 & I appreciate the following in myself & .869 & & & \\
\hline 59 & I appreciate the following in others & .869 & & & \\
\hline 25 & I would rather do... & .834 & & & \\
\hline 48 & I achieve the best results when I rely on... & .828 & & & \\
\hline 28 & I am more interested in... & .810 & & & \\
\hline 14 & $\begin{array}{l}\text { When I start doing something (e.g. writing homework), } \\
\text { I prefer... }\end{array}$ & .807 & & & \\
\hline 41 & When I perform daily tasks, I frequently use... & .803 & & & \\
\hline 32 & It is better to: & .797 & & & \\
\hline 49 & In each issue I prefer... & .784 & & & \\
\hline 64 & I mostly think about... & .776 & & & \\
\hline 27 & I like to: & .756 & & & \\
\hline 17 & When I need to do something important... & .740 & & & \\
\hline 12 & $\begin{array}{l}\text { Between good practice and interesting imagination, I } \\
\text { would rather choose... }\end{array}$ & .737 & & & \\
\hline 07 & $\begin{array}{l}\text { When I participate in group work (e.g. solving some } \\
\text { tasks), my role is most often... }\end{array}$ & .736 & & & \\
\hline 31 & I prefer to... & .732 & & & .492 \\
\hline 06 & I prefer work that is... & .727 & & & \\
\hline 58 & $\begin{array}{l}\text { My friends tell me that my attitude toward group tasks } \\
\text { is... }\end{array}$ & .722 & & & \\
\hline 47 & I live my life by mostly... & .700 & & & .325 \\
\hline
\end{tabular}

TABLE 5. PRINCIPAL COMPONENT MATRIX [TABELA 5. MATRICA SKLOPA IZDOVJENIH KOMPONENTI] 


\begin{tabular}{|c|c|c|c|c|c|}
\hline 45 & I more often do things that are: & .682 & & & \\
\hline 03 & I prefer when things are: & .663 & & & .300 \\
\hline 63 & I think games would be more fair if kids would... & .662 & & & \\
\hline 35 & When I do some work that requires precision: & .594 & & & \\
\hline 44 & When I travel from point "A" to point "B" I will go ... & .581 & & & .315 \\
\hline 04 & In any activity it is more important to... & .506 & & & \\
\hline 60 & It is easier for me to agree with my friends... & .489 & & & \\
\hline 61 & When I get up in the morning... & .471 & & & .486 \\
\hline 43 & If I get a bad grade, I usually react... & -.469 & & .341 & \\
\hline 33 & If one of my friends is sad because he has a problem ... & -.318 & & & \\
\hline 24 & In Serbian language lesson, I prefer when we analyze... & & & & \\
\hline 39 & I prefer to have... & & .945 & & \\
\hline 05 & I spend my time: & & .918 & & \\
\hline 26 & After an exhausting week, on weekends I prefer to... & & .913 & & \\
\hline 36 & When I have free time, I prefer to ... & & .840 & & \\
\hline 08 & After a day spent with a lot of people: & & .818 & & \\
\hline 11 & My friends see me as: & & .771 & & \\
\hline 15 & When there is some news at school, I usually find out... & & .753 & & \\
\hline 56 & I can say for myself that I am a little more... & & & & .425 \\
\hline 01 & When I am sad, I prefer to be ... & & .575 & & .358 \\
\hline 51 & In regard to phone use, I... & & .537 & & .440 \\
\hline 21 & At parties and with people in general, I mostly... & & .508 & & \\
\hline 53 & I prefer teachers who are... & & .426 & & \\
\hline 16 & $\begin{array}{l}\text { When I see someone crying, I would approach him/ } \\
\text { her.... }\end{array}$ & & & & \\
\hline 52 & $\begin{array}{l}\text { In my relationship with my friends, what matters to me } \\
\text { is what they... }\end{array}$ & & & .787 & \\
\hline 46 & It's easier for me to notice: & & & .780 & \\
\hline 30 & It's easier for me to react to someone else's... & & & .762 & \\
\hline 19 & It is more important to me what someone... & & & .742 & \\
\hline 23 & When I'm worried, I... & & & .671 & .382 \\
\hline
\end{tabular}

TABLE 5. PRINCIPAL COMPONENT MATRIX [TABELA 5. MATRICA SKLOPA IZDOVJENIH KOMPONENTI] 


\begin{tabular}{|c|c|c|c|c|}
\hline 40 & As for my feelings, I usually... & & 609 & .343 \\
\hline 54 & When I get into an argument, I usually... & & .559 & -.456 \\
\hline 22 & When I argue with a person dear to me ... & & .544 & \\
\hline 37 & In books and movies, I prefer... & & .419 & \\
\hline 02 & I believe more... & & .355 & \\
\hline 13 & It's easier for me to learn a lesson... & & & \\
\hline 18 & Friends think that I am... & .390 & & .757 \\
\hline 10 & When I am in a group I mostly: & .336 & & .755 \\
\hline 50 & I usually... & .393 & & .728 \\
\hline 42 & I would rather: & & & .718 \\
\hline 09 & My friends say about my personality... & & .364 & -.576 \\
\hline 29 & Most people describe me more as: & .470 & & \\
\hline & \multicolumn{4}{|c|}{$\begin{array}{l}\text { Extraction Method: Principal Component Analysis. } \\
\text { Rotation Method: Varimax with Kaiser Normalization. }\end{array}$} \\
\hline & \multicolumn{4}{|l|}{ a. Rotation converged in 6 iterations. } \\
\hline
\end{tabular}

TABLE 5. PRINCIPAL COMPONENT MATRIX [TABELA 5. MATRICA SKLOPA IZDOVJENIH KOMPONENTI]

We can see from Table 5 that as many as 36 items with a saturation of over 0.3 saturate the first extracted factor. The items that most saturate this factor are items under numbers 55, 57, 34, and 32. The second extracted factor is saturated with a total of 15 items with a saturation of over 0.3 . It is most saturated with items 39,5 and 26. The third factor is saturated by 12 items with saturation over 0.3. Items under numbers 52,46 , and 30 saturate this factor the most. The fourth factor is saturated with 16 items with saturation over 0.3. Concerning this factor, items 18,10 and 50 show the highest factor saturation.

EXTERNAL Test validity was examined with respect to an external criterion: VALIDITY assessment of learning style by the teacher. Teachers first received a detailed description of each of the learning style dimensions, and then assessed which of the mentioned poles of each dimension each student would prefer (which would be more suitable for each student, based on their characteristics). Teachers' assessments were compared with values for dimensions obtained empirically through the Learning Style Inventory. Pearson correlation coefficients are shown in Table 6. The same table also shows the correlation 
between each dimension (empirically obtained and assessed by the teacher) and the average student achievement in school.

\begin{tabular}{|c|r|r|r|r|}
\hline & E-I ASSESS. & S-IN ASSESS. & \multicolumn{1}{|c|}{ O-M ASSESS. } & \multicolumn{1}{c|}{ J-P ASSESS. } \\
\hline E-II &, $619^{* *}$ &, $232^{*}$ &, $365^{* *}$ &, $302^{* *}$ \\
\hline S-IN &, 127 &, $850^{* *}$ &, 184 &, $904^{* *}$ \\
\hline O-M &, 162 &,$- 238^{*}$ &, $329^{* *}$ &,$- 212^{*}$ \\
\hline J-P &, 060 &, $846^{* *}$ &, 132 &, $907^{* *}$ \\
\hline &, 550 &, 000 &, 191 &, 000 \\
\hline \hline
\end{tabular}

TABLE 6. CORRELATION OF LEARNING STYLES ASSESSED BY TEACHERS AND STUDENTS

[TABELA 6. KORELACIJA STILOVA UČENJA PROCENJENIH OD STRANE UČITELJA I UČENIKA]

** Correlation is significant at the level of 0.01 .

* Correlation is significant at the level of 0.05 .

Legend:

E-I assess. (assessment of E-I dimension by teachers); E-I - extraversion-introversion dimension obtained by the learning style inventory; $\mathrm{S}$-iN assess. (assessment of S-iN dimension by teachers); S-iN sensing-intuition dimension obtained by the learning style inventory; $\mathrm{O}-\mathrm{M}$ assess. (assessment of $\mathrm{O}-\mathrm{M}$ dimension by teachers); O-M feeling-thinking dimension obtained by the learning style inventory; J-P assess. (assessment of J-P dimension by teachers); J-P - judgment-perception dimension obtained by the learning style inventory;

We can see from Table 6 that in regard to assessment by teachers (as an external criterion), their assessments show statistically significant positive and high correlation with the following learning style dimensions obtained by the learning style inventory: extraversion-introversion $(r=.619$. $\mathrm{P}<0,01)$; sensing-intuition $(\mathrm{r}=.850, \mathrm{p}$ $<0.01)$, judgment-perception $(r=.907 . p<0.01)$. With regard to the feeling-thinking dimension, it shows a statistically significant correlation of medium intensity with teachers' assessments $(r=.329$. $\mathrm{P}<0.01$ ).

\section{CONNECTION BETWEEN THE DIMENSIONS OF THE MB LEARNING STYLE MODEL AND CERTAIN SOCIO-DEMOGRAPHIC CHARACTERISTICS}

Examining the connection between the prevalent poles of the dimensions of the MB learning style model and respondents' gender, as well as the average student achievement in school. 
The difference in the proportions of the prevalent poles of the dimensions of the MB learning style model with respect to respondents' gender was examined. Chi square analysis was used. The results show that there is no significant difference with respect to the proportion of prevalent poles of the MB model dimensions between male and female respondents.

\begin{tabular}{|c|l|r|r|r|r|r|c|}
\hline DIMENSION & PREVALENT DIMENSION POLE & \multicolumn{1}{|c|}{$\mathrm{N}$} & \multicolumn{1}{c|}{ MEAN } & STD. DEVIATION & \multicolumn{1}{c|}{ T } & \multicolumn{1}{c|}{ DF } & \multicolumn{1}{c|}{ SIG } \\
\hline \multirow{2}{*}{ E-I } & Extraversion & 74 & 4.462 & 0.54 & 1.433 & 98 & .155 \\
\cline { 2 - 9 } & Introversion & 26 & 4.292 & 0.38 & & & \\
\hline \multirow{2}{*}{ S-IN } & Sensing & 54 & 4.626 & 0.45 & 4.818 & 98 & .000 \\
\cline { 2 - 9 } & Intuition & 46 & 4.178 & 0.46 & & & \\
\hline \multirow{2}{*}{ F-T } & Feeling & 64 & 4.431 & 0.51 & .288 & 98 & .774 \\
\cline { 2 - 9 } & Thinking & 34 & 4.400 & 0.51 & & & \\
\hline \multirow{2}{*}{ J-P } & Judgment & 51 & 4.622 & 0.45 & 4.451 & 98 & .000 \\
\cline { 2 - 9 } & Perception & 47 & 4.202 & 0.47 & & & \\
\hline \hline
\end{tabular}

TABLE 7. CONNECTION BETWEEN THE PREVALENT POLES OF THE DIMENSIONS OF THE MB LEARNING STYLE MODEL AND AVERAGE STUDENT ACHIEVEMENT IN SCHOOL [TABELA 7. POVEZANOST IZMEĐU RASPROSRANJENIH POLAVA DIMENZIJA MB STILOVA UČENJA I PROSEČNOG POSTIGNUĆA UČENIKA U ŠKOLI]

Results in Table 7 show that there is a significant difference in the average achievement of students with regard to the preferred poles of learning style dimensions sensing-intuition and judgment-perception. In regard to the sensing-intuition dimension, the results show that students who prefer the sensing pole in this learning style dimension have better average school achievement compared to students who prefer intuition pole $(\mathrm{t}=4,818, \mathrm{df}=98$, $\mathrm{p}<0,01)$. Moreover, students who prefer judgment pole in the judgment-perception dimension have statistically significantly higher average school achievement than students who prefer perception pole on this dimension.

\section{DISCUSSION AND CONCLUSION}

The main goal of this study was to examine reliability and validity of the ISUMB2-O instrument, which is Learning Style Inventory for 
primary school children based on Myers-Briggs learning style model. This instrument relies on the Paragon Learning Style Inventory (Shindler, 2000), which is a slightly shorter version of the MBTI inventory. The data obtained related to reliability, both for individual dimensions (expressed via the Cronbach's alpha coefficient) and based on item analysis, indicate that it is a stable instrument that has high performance. The fact that Cronbach's alpha was over 0.93 for as many as three dimensions indicates that it is a highly reliable instrument. The results are consistent with reports from previous research in our region (Randjelović, 2012), and indirectly confirm the findings of researchers who checked the psychometric characteristics of the original Paragon Learning Style Inventory (Shindler, 2003; Garner-O'Neale \& Harrison, 2013; Aliakbari \& Abol-Nejadian, 2015; Khaki, Ganjabi \& Khodamoradi, 2015) which showed a solid reliability of all dimensions of the MB model. Based on the item analysis (Tables 2.1 to 2.4), it can be seen that most items have high correlation with the overall score for the individual dimensions. Moreover, these tables also show that the elimination of some items within certain dimensions of learning styles would not significantly improve the reliability of the entire dimension, that is, in some cases it would even decrease. All this points to the stability of the instrument as a whole, as well as the recommendation that the set of items within individual dimensions should remain as it is at the moment.

ISUMB2-O instrument validity was verified in two ways. Construct validity was checked by using factor analysis and external validity was checked by using the degree of correlation of values obtained based on the dimensions of learning styles with the instrument ISUMB2-O and on the teachers' assessment of individual poles of the examined dimensions of learning styles in their students based on the descriptions they received. In regard to construct validity, the principal component method and extraction based on Kaiser Criterion were used to check the four-factor solution. Although the preliminary analysis singled out several factors with the eigenvalue over 1 , the Scree plot and the fact that only four extracted factors had more than 3 items that saturate individual factors with saturation over 0.3 , we believe that the four-factor solution is the optimum and best possible solution in terms of the given instrument. Table 3 shows that the four-factor solution can explain $57 \%$ of the total variance. Horn's parallel analysis confirmed that the four-factor solution can be accepted. 
A more detailed analysis of the selected factors and the individual items that most saturate each of them (see Table 4), provides information that does not fully agree with the theoretical model. Namely, when the first extracted factor is in question, it is described by as many as 36 items with a saturation over 0.3 . The items that saturate this factor to the highest extent are the items (with saturation over 0.90) under number 55 (When I study something, I usually do it: a/ with a plan and in a specifically determined order and schedule, b/ without a plan, I first study what I like more at that moment or what seems easier to learn, 57 (I like to do things...a/ in a specific order; $b /$ in the way I believe is the best), and 32 (It is better to...a/ accept things as they are, $b /$ try to change them). Insight into the content of the items makes it clear that this factor mostly relates to the judgment-perception dimension (J-P). However, the following items that stand out for the same factor, also with high saturation (over 0.88 ), are item 62 (When I need to do something very important, I do it... a) in the old and proven way, which I always use, b) in a whole new way that I just came up with) and item 20 (I like work that requires...... a/ practice and skill, $b /$ imagination and new solutions), theoretically fit more into the explanation of the sensing-intuition dimension (S-iN). Therefore, this factor would cover more items than both dimensions (both J-P and S-N). High correlation between these two dimensions, as well as their overlap in the factor structure was also confirmed with the original MBTI instrument (Kirby \& al., 2007). This may be due to a higher order factor that encompasses both dimensions. This is a question for some future research and the possible use of higher order factor analysis. When it comes to the extracted factors two and three (see Table 6), everything is quite clear. Namely, the second extracted factor has a total of 15 items with a saturation higher than 0.3 and is most saturated with items no. 39 (I prefer to have...a/ a lot of friends, $b /$ few friends) , 5 (I spend my time a) in larger groups of people, and rarely alone, $b /$ in smaller groups of people or alone) and 26 (After an exhausting week, on weekends I prefer to....... / I go out and play with others, b/I stay home to rest or play alone). The content of the above-mentioned items clearly shows that this is the extraversion-introversion dimension (E-I). All 15 items that saturate the mentioned factor are precisely intended for measuring the E-I dimension, as indicated in the key for result calculation (Ranđelović, 2012). The situation is similar with the third extracted factor. As for this factor, there are a total of 12 items with saturation over 0.3 , and the items with the highest saturation are: 52 (In 
my relationship with my friends, what matters to me is what they..... a/ feel, b/ think), and item 46 (It's easier for me to notice: a/ what someone else feels, b/ what someone else thinks) and item 30 (It's easier for me to react to someone else's... a/ )...feelings, b/ ...opinions). This is the feeling-thinking dimension (F-T) and all twelve items refer to this dimension. As for the fourth extracted factor, it is saturated with items from as many as three different dimensions of learning styles: mostly from the extraversion-introversion dimension, followed by the feeling-thinking dimension and finally the judgment-perception dimension. Items within the selected factors are grouped in such a way that the first three extracted factors cover as many as 57 out of 64 items and this factor refers to the dimensions $\mathrm{J}-\mathrm{P}$ and S-N; the second factor covers items related to the E-I dimension, and the third factor is saturated by items related to the F-T dimension.

In regard to the external validity of the instrument, it has been shown that ISUMB2-O truly adequately determines the affiliation to the certain poles of the dimensions of the MB learning style model. Namely, based on the results from Table 5, there is a statistically significant positive correlation between the results for the dimensions of the inventory of learning styles and the teachers' assessment of individual poles of the examined dimensions of learning styles in their students based on the descriptions they received. This correlation is high in the case of dimensions E-I, S-N and $\mathrm{J}-\mathrm{P}$, and of medium intensity for the F-T dimension. This actually means that the classification of students into individual subgroups based on the results on the inventory of learning styles (extravert-introvert, sensing-intuitive, feeling-thinking, and judgment-perception types), as well as specifying the characteristic type of learning style for each individual student based on the combination of results for the dimensions are correct and based on the actual preferences of students. This type of instrument validation was also used in the case of the original version of the MBTI instrument (Kirby \& al., 2007), but in that case self-assessment was used (based on the descriptions that individuals received about each learning style dimension), because respondents were adults, and in our case we are talking about children up to 11 years of age, so it was estimated that teachers' assessment (based on the description of the dimensions they received) was a more objective measure than students' assessment. Given the ambiguous findings related to the construct validity of the ISUMB2-O instrument, as well as fairly 
clear findings related to the undisputed external validity of the instrument, our final judgment on the overall validity of the instrument is that the instrument is valid, that its items and dimensions adequately reflect the MB model, that it provides the opportunity to objectively identify student learning styles and it gives the opportunity to use the results for the preparation of individualized learning programs that will encourage students to learn independently and lead to permanent improvement of learning content and reorganization of educational processes.

The results section also shows the data related to the relationship between the dimensions of MB learning style models and certain sociodemographic variables (gender and school achievement). From the aspect of gender, no significant statistical difference was found with respect to the proportion of prevalent poles of the MB model dimensions of learning styles between male and female respondents. These findings partially disagree with the results of previous research, especially when it comes to the F-T dimension. For example, in Kendall's research (Kendall, 1988), it was shown that there are pole-related differences for the F-T dimension and that women prefer feeling pole more than men do ( $70 \%$ of women surveyed, as opposed to $35 \%$ of men surveyed). On the other hand, there are findings indicating that the distribution of learning styles in males and females is very similar (Hargrove \& al., 2008), while a number of studies have found no significant differences between male and female students (Brew, 2002; Kayes, 2005; Metin \& al., 2011). It should be kept in mind that our sample consisted of children who are still forming their preferences in learning styles, just like value systems, since this dimension is also concerned with the domain of values, so in our opinion, it was somewhat expected that the differences that would probably appear at a later age still do not exist at that an early age. These findings are also confirmed by Randjelović (2012). Sensing-intuition and judgment-perception dimensions have proven to be related to school achievement. Students who prefer sensing pole within the S-N dimension and judgment pole within the judgment-perception dimension statistically have better average school achievement than students who prefer the intuition pole and perception pole within these learning style dimensions. The connection between these two dimensions was also confirmed in the research by Randjelović \& al. (2011), but in this research, the direction of the connection was reversed. However, in the mentioned research study, the respondents were high 
school students, and our sample included 4th grade primary school students. Interestingly, the author Sak (2004), used the MBTI instrument to synthesize the results of 14 different studies (total number of respondents $\mathrm{N}=5723$ ) that focused on personality characteristics (and related learning styles) of gifted students, states that intuitive types show far better school achievement compared to sensing types. Intuitive type is, by definition, more characterized by quickly coming up with solutions, inventiveness, they are imaginative, and they like to solve more complex problems that require vast theoretical knowledge and a higher level of abstraction (Stojaković, 2000). One longitudinal study (Felder \& al., 2002, according to Felder \& Brent, 2005) showed that intuitive type students, as opposed to sensing types, see themselves as much more successful when solving tasks that require creative problem-solving skills and emphasized that they would prefer to do creative work in the future. A large percentage of sensing type students saw themselves in the future as engineers in big companies, while a large percentage of intuitive type students planned to work in small companies or to continue their education and research. Sak also highlights certain differences in academic achievement and general cognitive abilities between different categories of learning styles: introvert intuitive types (INs) show far better academic achievement and more pronounced cognitive abilities compared to other categories of learning styles according to the MB model (Sak, 2004).

The conclusion is that the instrument showed good psychometric characteristics, primarily due to extremely high reliability, high values for item-total correlation, satisfactory construct validity, but also adequate external validity, which indicates that the instrument measures precisely those characteristics for which it was originally intended. However, the limiting factor related to the generalization of results should be taken into account, especially regarding the data related to the factor analysis because the sample included only 100 respondents (which is a small number in relation to the total number of variables). Of course, caution is advised, so before the wider use of the instrument, especially in school, it is recommended to check the characteristics of the instrument in other parts of the population for which it is intended, i.e. psychometric characteristics should be checked in $5^{\text {th }}, 6^{\text {th }}, 7^{\text {th }}$ and $8^{\text {th }}$ grade students. 
REFERENCES Aliakbari, M., Abol-Nejadian, R. (2015). Trait emotional intelligence and learning styles: the case of Iranian English for Academic Purposes learners. Journal of Educational and Social Research, 35(7), 779-793.

Bjekić, D., Dunjić-Mandić, K.(2007). Stilovi učenja i profesionalne preferencije maturanata gimnazije, Pedagogija, LXII, str. 48-59

Brew, C. R. (2002). Kolb's learning style instrument: sensitive to gender. Educational and psychological measurement, 62 (2), 373-390.

Cassidy, S. (2004). A learning style: An overview of theories, models and measures. Educational psychology, 24 (4), 419-444.

Coffield, F., Moseley, D., Hall, E., Ecclestone, K. (2004). Learning styles and pedagogy in post-16 learning: A systematic and critical review. London: Learning and skills research centre.

Curry, L. (1983). An organization of learning styles theory and constructs. ERIC.

Dunn, R., Honigsfeld, A., Doolan, L. S., Bostrom, L., Russo, K., Schiering, M. S. (2009). Impact of learning-style instructional strategies on students' achievement and attitudes: Perceptions of educators in diverse institutions. The Clearing House: A Journal of educational strategies, issues and ideas, 82 (3), 135-140.

Felder, R. M., Silverman, L. K. (1988). Learning and teaching styles in engineering education. Engineering education, 78 (7), 674-681.

Felder, R. Brent, R. (2005). Understanding student differences. Journal of engineering education, 94 (1), 57-72.

Gardner, H. (1983). Frames of mind: The theory of multiple intelligence. New York, besic Books.

Garner-O'Neale, L. Harrison, S. (2013). An Investigation of the Learning styles and Study Habits of Chemistry Undergraduates in Barbados and their Effect as Predictors of Academic Achievement in Chemical Group Theory. Journal of Educational and Social Research. 3(2), 107-122. DOI: 10.5901/ jesr.2013.v3n2p107.

Hargrove, K. S., Wheatland, J. A., Ding, D., Brown, C. M. (2008). The effect of individual learning styles on student GPA in engineering education at Morgan state university. Journal of STEM education: innovations and research, 9(3), 37-46.

Kayes, C. D. (2005). Internal validity and reliability of Kolb's learning style inventory version 3 (1999). Journal of business and psychology, 20 (2), 249-257.

Kirby, L. K., Kendall, E., Barger, N. J. (2007). Type and Culture; Using the MBTI ${ }^{\circledast}$ Instrument in International Applications. Mountain View, CA: CPP, Inc.

Kendall E. (1998): Myers-Briggs Type Indicator European English Edition Step I Manual Supplement. Mountain View, CA: CPP, Inc., 1998. 
Khaki, N, Ganjabi, M., Khodamoradi, A. (2015). The Effect of Learning Style on the Performance of Students in a Preemptive Focus-on-Form Instruction. Porta linguarum 24, 21-32

Kvaščev, R. (1978). Modeliranje procesa učenja. Prosveta, Beograd.

Kvaščev, R. (1980). Sposobnosti za učenje i ličnost. Zavod za udžbenike i nastavna sredstva, Beograd.

Kolb, D. A. (1976). The learning style inventory: Tehnical manual, MCBer, Boston, Ma.

Kolb, A., Kolb, D. (2005). Learning styles and learning spaces: Enhancing experiential learning in higher education. Academy of management learning \& education, 4 (2), 193- 212.

Li, Y. S., Chen, P. S., \& Tsai, S. J. (2008). A comparison of the learning styles among different nursing programs in Taiwan: implications for nursing education. Nurse Education Today, 28(1), 70-76.

Metin, M., Yilmaz, G. K., Salih, B., Kerem, C. (2011). The investigating pre-service teachers' learning styles with respect to the gender and grade level variables. Procedia-social and behavioral sciences, 15, 2728-2732.

Pritchard, A. (2009). Ways of learning: Learning theories and learning styles in the classroom. London: Routledge

Pušina, A. (2014). Stil u psihologiji: teorije i istraživanja. Sarajevo: Filozofski fakultet.

Ranđelović, D. (2012). Stilovi učenja i modeliranje procesa učenja. Doktorska disertacija. Banja Luka: Filozofski fakultet.

Ranđelović, D. (2013). Mogućnosti modeliranja procesa učenja u razrednoj nastavi. U: prof. dr B. Jovanović (glavni odgovorni ur) Pojedinac, porodica, društvo u tranziciji. Kosovska Mitrovica: Filozofski fakultet Univerziteta u Prištini sa privremenim sedištem u Kosovskoj Mitrovici, 283 303.

Ranđelović, D. (2014). Dominantni stilovi učenja kod srednjoškolaca. U: Miroslav Krstić, Dušan Ranđelović, Gordana Nikolić (ur) Mladi i društvene promene - između nacionalnog identiteta i evrointegracija. Tematski međunarodni zbornik radova. Kosovska Mitrovica: Filozofski fakultet, 291 309.

Sak, U. (2004). A Synthesis of Research on Psychological Types of Gifted Adolescents. The Journal of Secondary Gifted Education, 15 (2), 70-79.

Salter, D. W., Evans, N. J., \& Forney, D. S. (2006). A longitudinal study of learning style preferences on the Myers-Briggs type indicator and learning style inventory. Journal of college student development, 47 (2), 173-184.

Shindler, J. (2002). Exploring various structural options for performance assessment scale design: Which rubric is best? National Forum of Teacher Education Journal, 12, 3-12.

Shindler, J. (2003). Paragon learning style inventory. Retrieved September 15, 2011 from http://www.calstatela.edu/faculty/jshindl/plsi/ 
Shindler, J. (2004): Teaching for the Success of all Learning Styles: Five Principles for Promoting Greater Teacher Effectiveness and Higher Student Achievement for all Students, California State University, Los Angeles, skinuto sa sajta 20.01.2011, http://www.calstatela.edu/faculty/ jshindl/plsi/teachingacrosstype.htm

Shindler, J. (2004). Teaching for the Success of all Learning Styles: Five Principles for Promoting Greater Teacher Effectiveness and Higher Student Achievement for all Students, California State University, Los Angeles, skinuto sa sajta 20.01.2011, http://www.calstatela.edu/faculty/ jshindl/plsi/teachingacrosstype.htm

Stojaković, P. (2000). Kognitivni stilovi i stilovi učenja. Banja Luka: Filozofski fakultet.

Tabachnick, B.G. \& Fidell, L.S. (2007). Using multivariate statistics ( $\left.5^{\text {th }} \mathrm{edn}\right)$. Boston: Pearson Education.

Witkin, A. Goodenough, D. (1981). Cognitive style: Essence and Origins: Field dependence and field independence, New York, International Press

Zhang, L., Stenberg, R. (2011). Culture and intellectual styles. In L. Zhang, R. Stenberg, \& S. Rayner, Handbook of intellectual styles: Preferences in cognition, learning, and thinking. New York: Springer Publishing Company. 131-152.

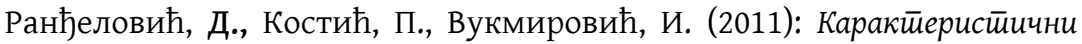

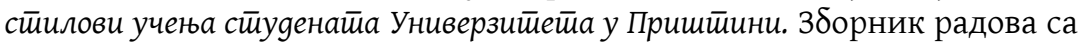
научног скупа са међународним учешћем, Пале: Филозофски факултет, 22-23. мај 2010., књига 5, том 2, стр. 639-650. Тема скупа: Наука и политика. Главни и одговорни уредник: проф.др Милош Ковачевић.

Ранђеловић, Д. (2016). Стиловиучењастуденатауниверзитета у Нишу. У проф. др Бојана Димитријевић и Александар Благојевић (главни и одговорни ур.) Менӣално зgравље млаgих,. Ниш: Филозофски факултет и Студентски културни центар Ниш. стр 177-197.

\section{ДУШАН Ј. РАНЋЕЛОВИЋ}

УНИВЕРЗИТЕТ У ПРИШТИНИ СА ПРИВРЕМЕНИМ СЕДИШТЕМ

У КОСОВСКОЈ МИТРОВИЦИ, ФИЛОЗОФСКИ ФАКУЛТЕТ

КАТЕДРА ЗА ПСИХОЛОГИЈУ

МИЉАНА С. ПАВИЋЕВИЋ

УНИВЕРЗИТЕТ У ПРИШТИНИ СА ПРИВРЕМЕНИМ СЕДИШТЕМ

У КОСОВСКОЈ МИТРОВИЦИ, ФИЛОЗОФСКИ ФАКУЛТЕТ

КАТЕДРА ЗА ПСИХОЛОГИЈУ 
Последњих тридесетак година у фокусу истраживачке пажње стручњака у области психологије образовања је сам процес учења, за разлику од раније фаворизованих исхода учења. С тим у вези, једна од доминантних тема су и стилови учења. Постулиран је велики број модела и класификација различитих стилова учења, као и инструмената који служе за идентификовање карактеристичних начина учења ученика. Један од савремених модела стилова учења који има широку примену у школској пракси је и Мајерс-Бригсов модел стилова учења. По овом моделу, индивидуални профил стила се одређује на основу положаја дуж четири биполарне димензије: екстравертност/интровертност, чулност/интуитивност, размишљање/осећање и просуђивање/перцепција.

Циљ рада је био проверавање поузданости и ваљаности инвентара стилова учења за основце ИСУМБ2-О. Овај инвентар је базиран је на Мајерс-Бригсовом моделу стилова учења, а сам модел у својој основи има Јунгову типологију личности. Инструмент је конструисан на основу Парагоновог инвентара стилова учења и први пут је употребљен на основцима у Републици Србији 2012. године. Аутор наводи да се после више пилот-истраживања (Н> 850 ) на узорцима ученика IV, V, VI и VII разреда основних школа у Нишу и Косовској Митровици, и вишеструких модификација, дошло до коначне форме инструмента са 64 ставке (за сваку од димензија по 16 ставки).

Добијени резултати (на узорку од 100 ученика IV разреда основних школа у Нишу) везани за поузданост, како за поједине димензије (изражене преко Кронбах алфа коефицијента) тако и на основу ајтем анализе, указују на то да се ради о стабилном инструменту. Три од четири димензије имају поузданост изнад 0,93 изражену Кронбах алфа коефицијентом. Ваљаност је испитивана на два начина: а) конструкт ваљаност је проверавана преко факторске анализе како би се проверила факторска структура инструмента; $\delta$ ) проверавана је екстерна ваљаност преко степена корелације вредности добијених на димензијама стилова учења на инструменту ИсуМБ2-О и процена наставника појединих полова испитиваних димензија стилова учења код њихових 
ученика на основу описа који су добили. Четворофакторско решење је оптимално и најбоље могуће у погледу датог инструмента и оно може да објасни 57\% укупне варијансе. Постоји статистички значајна позитивна корелација између резултата на димензијама инвентара стилова учења и процена наставника појединих полова испитиваних димензија стилова учења код њихових ученика на основу описа који су добили. Та корелација је велика у случају димензија Е-И, С-Н и J-п, а средњег интензитета када је у питању димензија $\Phi$-Т. Нису добијене полне разлике у стиловима учења, док су димензије сензација-интуиција и суђење-перцепција повезане са школским успехом.

Закључак је да је инструмент показао добре психометријске карактеристике, сагледане, пре свега, преко изузетно високе поузданости, високих вредности за ајтем-тотал корелације, задовољавајуће конструкт валидности, али и адекватне екстерне валидности, које указују на то да инструмент мери управо оне карактеристике за које је изворно и намењен. Истакнута су и ограничења истраживања, поготову она везана за величину узорка.

КљУчнЕ РЕчи: психометријске карактеристике; инвентар стилова учења; Мајерс-Бригсов модел.

Овај чланак је објављен и дистрибуира се под лиценцом Creative Commons Ауторство-Некомерцијално Међународна 4.0 (CC BY-NC 4.0 |

https://creativecommons.org/licenses/by-nc/4.0/).

This paper is published and distributed under the terms and conditions of the Creative Commons Attribution-NonCommercial International 4.0 licence (CC BY-NC 4.0 | https://creativecommons.org/licenses/by-nc/4.0/). 